\author{
Adrianna Adamek-Świechowska \\ (Uniwersytet Gdański)
}

\title{
Henryk Sienkiewicz WObec myśli politycznej EMIGRACJI POLSKIEJ W SZWAJCARII*
}

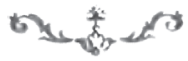

Kościół narodowy ma szerokie podwoje. Trzeba zawsze patrzyć na niezmierną wielkość idei, nie zaś na przypadkową małość niektórych jej wyznawców.

Henryk Sienkiewicz, Zjednoczenie narodowe ${ }^{1}$

$\mathrm{P}^{\mathrm{a}}$ O WYBUCHU „WIELKIEJ WOJNY” nasiliły się działania kół emigracyjnych zmierzające do odrodzenia państwowości polskiej. Szczególna rola przypadła środowiskom szwajcarskim, w których aktywność w tej sferze miała ambitne założenia. Uprzednio po upadku powstania styczniowego powstało założone przez Władysława Broel-Platera Muzeum Narodowe Polskie, mające za zadanie „pracować nad odrodzeniem moralnym narodu” jako gwarancji „odrodzenia materialnego” ${ }^{2}$. Helwecką przestrzeń oddziaływania wyróżniała także jej neutralna pozycja w Europie rozdartej przez ścierające się nawzajem wrogie armie Ententy i państw centralnych. Jak stwierdził Władysław Baranowski w omówieniu problemu kwestii polskiej w tych kręgach emigracyjnych: „Szwajcaria przez swe położenie geograficzne, przez

* Artykuł powstał w ramach realizacji projektu badawczego Henryk Sienkiewicz. Obecność w kulturze polskiej XX wieku. Polskość i nowoczesność. Recepcja i nowe odczytania, finansowanego ze środków Narodowego Centrum Nauki, przyznanych na podstawie decyzji DEC-2012/o6/A/HS2/00252.

1 H. Sienkiewicz, Zjednoczenie narodowe, w: tegoż, Dwie łąki, Warszawa 1908, s. 215. Pierwodruk: „Dziennik Poznański” 1906, nr 257.

2 A. Lewak, Muzeum Narodowe Polskie w Rapperswilu 1869-1927, Warszawa 1938, s. 7. 
trójjęzyczną ludność, stała się terenem, na którym może najsilniej ścierają się opinie o dzisiejszej wojnie, często we wręcz odmiennym oświetleniu" ${ }^{3}$.

W sprzyjających warunkach mogła się rozwijać „zakulisowa gra polityczna, zwana dyplomacją”, a skoncentrowanie się „służby prasowej największych dzienników świata" umożliwiało prowadzenie nieskrępowanej propagandy. Zasadniczym jednak problemem utrudniającym jasny odbiór kwestii polskiej przez cudzoziemców była różnorodność stanowisk. Polityczna myśl polska rozpadała się - mimo świadomości, że należy „przedstawiać siłę jednolitą i doskonale zorganizowaną" ${ }^{4}$ - na dwie zwalczające się orientacje: antyrosyjską i antyniemiecką.

W obliczu możliwej niepodległości rodziły się nie tylko wielkie cele, ale i nieporozumienia, których źródłem były odmienne poglądy i osobiste ambicje działaczy. „Wobec powagi rozgrywającego się przełomu”, mogącego doprowadzić do odrodzenia ojczyzny, jak tę sytuację ujmowano, brakowało jedności: „[...] co Polak, to nowy jej zbawca i lekarz, co ugrupowanie, to nowe jej sztandary, co papier zapisany - nowe hasło i krytyka tego, co się stało, co jest i się czyni" ${ }^{5}$. Autorzy odezw w przekonaniu o niezbitej słuszności swych poglądów ogłaszanych na łamach prasy i w formie odbitek czy broszur usiłowali pozyskać dla swej orientacji niezdecydowanych lub przyjmujących postawę neutralną. Na celowniku walk propagandowych znajdował się Henryk Sienkiewicz jako Polak o „fascynującym cudzoziemców nazwisku" ${ }^{6}$ i jako prezes Komitetu Pomocy dla ofiar wojny w Polsce, organizacji filantropijnej, reprezentującej polski interes. Oczekiwania wobec znanego w świecie orędownika sprawy polskiej dyktowało przekonanie, iż jego stanowisko zostanie odebrane na arenie międzynarodowej jako „wyraz opinii i żądań narodu polskiego w tej dziejowej chwili" ?.

Postawa Sienkiewicza wobec kwestii politycznych w tym okresie była niejednokrotnie przedmiotem badań, co znalazło swój wyraz w licznych pracach historycznych i historycznoliterackich ${ }^{8}$. Dlatego też stanowisko pisarza

3 W. Baranowski, Sprawa polska w prasie francusko-szwajcarskiej (odbitka z „Kroniki Polskiej"), Lozanna 1916, s. 3.

4 T. Szpotański, W imię niepodległości, „Listy Ulotne do Emigracji Polskiej w 1915 r.” (Lozanna), t. 1 (sierpień), s. 21.

5 W.B., Bez jedności, jw., s. 1.

6 W.B., Polityka czy filantropia? Przyczynki do działalności Komitetu Veveyskiego, jw., s. 32.

7 Tamże.

8 Zob. J. Pajewski, Wokół sprawy polskiej. Paryż-Lozanna-Londyn 1914-1918, Poznań 1970; D. Płygawko, Sienkiewicz w Szwajcarii. Z dziejów akcji ratunkowej dla Polski w czasie pierwszej wojny światowej, Poznań 1986; W. Śladkowski, Opcje polityczne Henryka Sienkiewicza w latach 1914-1916, w: Henryk Sienkiewicz. Twórczość i recep- 
jest na ogół znane, jakkolwiek budzi niezmiennie różne kontrowersje, co jest wynikiem zarówno znacznego zawikłania stosunków politycznych, podlegających dynamicznym zmianom, jak i oddziaływania odmiennych, niekiedy także tendencyjnych interpretacji ${ }^{9}$. Jest to także rezultat faktu, że poglądy autora Quo vadis? ewoluowały pod wpływem zachodzących zmian politycznych, w tym także przejawów aktywności polskich działaczy. Kontekst ten jest nieodzownym elementem pozwalającym na to, by opisać uwarunkowania towarzyszące stanowisku Sienkiewicza wobec tych zagadnien ${ }^{10}$. Ewolucja postawy pisarza jako prezesa Komitetu Veveyskiego budzi zatem nieustannie zainteresowanie w związku z wypływającymi nowymi źródłami, dotyczącymi życia politycznego emigracji szwajcarskiej. Rzucają one nowe światło na relacje w kręgu szwajcarskiej emigracji, a tym samym pozwalają sienkiewiczologowi przybliżyć obraz ostatnich lat życia pisarza. Warto go uszczegółowić z uwagi na nadawane Sienkiewiczowi nie bez słuszności znaczenie w odzyskaniu przez Polskę niepodległości. Możliwość taką stwarza wykorzystanie nieuwzględnionych dotąd źródeł, pochodzących ze spuścizny Karola i Michała Potulickich, znajdującej się w archiwum Muzeum Narodowego Polskiego w Rapperswilu ${ }^{11}$.

W archiwum rodzinnym, zwanym początkowo spuścizną zmarłego bezpotomnie Michała hrabiego Potulickiego (1897-1984), zostały znalezione nieznane listy Henryka Sienkiewicza do Karola Potulickiego (1861-1931), prawnika, byłego ziemianina wielkopolskiego, publicysty, emigracyjnego działacza społecznego i politycznego, ojca właściciela przekazanych w darze

cja, pod red. L. Ludorowskiego, Lublin 1991, s. 405-418; H. Florkowska-Frančić, Veveyskie lata Henryka Sienkiewicza. Między dobroczynnościa a polityką, „Ruch Literacki” 1996, nr 4, s. 417-430; H. Florkowska-Frančić, Między Lozanna, Fryburgiem i Vevey. Z dziejów polskich organizacji w Szwajcarii w latach 1914-1917, Kraków 1997.

9 Aktualne pozostaje stwierdzenie Juliana Krzyżanowskiego, iż materia zagadnień związanych z działalnością polityczną Sienkiewicza stanowi swoiste wyzwanie poznawcze - „[...] tutaj jego biograf staje wobec kłębowiska zjawisk bardzo trudnych do ujęcia" (J. Krzyżanowski, Henryka Sienkiewicza żywot i sprawy, Warszawa 1976, s. 231).

10 Postulat ten zaakcentował Wiesław Śladowski, przestrzegając przed jednostronnością etykietek politycznych. W. Śladkowski, dz. cyt., s. 406.

11 Charakterystykę tego zbioru przedstawiła Ewa Furmańska. Zob. E. Furmańska, Pasje zbierackie na przykładzie Archiwum Rodziny Potulickich, „Zeszyty Historyczne” 2010, t. 11: Materiały z Międzynarodowej Konferencji Naukowej „Z dziejów emigracji polskiej XVIII-XX wieku. Muzeum Polskie w Rapperswilu”, s. 151-166; E. Furmańska, Pasje zbierackie na przykładzie Archiwum Rodziny Potulickich, „Nasza Gazetka. Polnische Zeitschrift in der Schweiz” 2012, nr 4/277, s. 28-32; E. Furmańska, Kolekcja Potulickich w zbiorach Muzeum Polskiego w Rapperswilu, „Archeion” 2014, t. 115, s. 335-352. 
dla Muzeum w Rapperswilu materiałów ${ }^{12}$. Dokumenty trafiły do zbiorów za pośrednictwem spadkobierców zmarłych w Szwajcarii dwóch przedstawicieli starszej linii rodu Potulickich.

Hrabia Karol Wincenty Heliodor Potulicki był czwartym synem Józefa i Ofelii Skórzewskiej, studiował prawo na Uniwersytecie Jagiellońskim, uzyskując w 1891 roku tytuł doktora obojga praw, przez dziesięć lat prowadził wielkopolskie gospodarstwo, nabyte w 1899 roku od Deutsche Ansiedlungsbank: Kruszewo z folwarkiem Bronisławki. Po sprzedaży majątków zakupił rezydencję Pré Bailly w Gex we Francji, którą po wybuchu pierwszej wojny światowej oddał do dyspozycji francuskiego Czerwonego Krzyża. Osiedlił się w pobliskiej Genewie, włączając się aktywnie w działania organizacji polskich na terenie Szwajcarii, prowadząc akcję publicystyczną i odczytową na rzecz niepodległości Polski. Należał do członków rady kierowanego przez Jana Kucharzewskiego propagandowego stowarzyszenia „La Pologne et la Guerre”, był członkiem rady nadzorczej wychodzącego w Lozannie pisma „Le Moniteur Polonais”, członkiem zarządu „Bureau International pour la Défense du Droit des Peuples” w Genewie, prezesem towarzystwa „Pro Polonia”, zbierającego fundusze dla kraju, oraz „Ogniska” skupiającego polską kolonię w Genewie ${ }^{13}$. W ramach tych ugrupowań organizował pomoc dla Polaków, jeńców wojennych. Należał również do zarządu Muzeum Narodowego w Rapperswilu.

Współpraca z Komitetem Międzynarodowego Czerwonego Krzyża i „Agence Internationale des Prisonniers de Guerre” umożliwiała Karolowi Potulickiemu pośrednictwo w dostarczaniu korespondencji polskich jeńców pozostających w niewoli obu walczących stron. Świadectwem tej działalności

12 Skany niepublikowanych dokumentów (listu i telegramu Henryka Sienkiewicza do Karola hr. Potulickiego, jak też trzech listów żony pisarza, Marii z Babskich Sienkiewiczowej oraz telegramu Antoniego Osuchowskiego w sprawie pogrzebu autora Trylogii 22 listopada 1916 roku do tego adresata) wykonałam podczas kwerendy w Bibliotece i Muzeum Narodowym w Rapperswilu. Listy Sienkiewicza znalazły się także za sprawą prof. Haliny Florkowskiej-Frančić w przygotowywanym przez prof. Marię Bokszczanin do druku nowym tomie odnalezionej w ostatnim czasie korespondencji. Dziękuję Paniom archiwistkom: Izie Gass i Ewie Furmańskiej za udostępnienie materiałów w nadzwyczajnych okolicznościach świątecznej, burzliwej nocy rapperswilskiej, jak również wyrażam wdzięczność Pani Prof. Marii Bokszczanin za możliwość wglądu w nowe nabytki Archiwum Listów Henryka Sienkiewicza w IBL PAN.

13 Zob. S. Leitgeber, Potuliccy, Londyn 1990, s. 111-113 oraz biogram w: Polski Słownik Biograficzny, t. 28, Wrocław 1985, s. 249. Warto nadmienić, że autorka biogramu, Alina Szklarska-Lohmannowa przypisuje Potulickiemu autorstwo anonimowej broszury prorosyjskiej La Question Polonaise par un Polonais de Posnanie, czemu zdaje się przeczyć Halina Florkowska-Frančić (Między Lozanną, Fryburgiem i Vevey, s. 254). 
są adresowane do niego listy Marii z Babskich Sienkiewiczowej, wskazujące zarazem na związki z Komitetem Veveyskim, w którym korespondencją zajmowała się żona pisarza ${ }^{14}$. Wszystkie trzy listy zawierają prośbę o pośrednictwo w doręczeniu pism do Warszawy. Jak dalece cenna to była pomoc, świadczy nie tylko treść życzeń, ale i wzmianka Sienkiewicza w liście do Ignacego Chrzanowskiego: „Z Warszawą komunikacja nasza zupełnie od 5 września przerwana. Marek wielce na to narzeka" ${ }^{15}$. Dzięki stosunkom Karola Potulickiego korespondencja Sienkiewicza i Komitetu Pomocy Ofiarom Wojny w Polsce, konfiskowana w kraju, mogła być doręczana. O wcześniejszych relacjach towarzyskich z pisarzem zaświadcza uczestnictwo młodego hrabiego Potulickiego w „żywych obrazach” z Ogniem i mieczem, zorganizowanych przez Juliusza Kossaka w 1884 roku w teatrze krakowskim według układu Jacka Malczewskiego. Wystąpił on w roli towarzysza pancernego w napierśniku husarskim ${ }^{16}$.

14 Maria z Babskich Sienkiewiczowa prowadziła dziennik korespondencji i pomagała w odpowiadaniu na ogrom pism napływających do Vevey. Dziennik znajduje się w zbiorach Muzeum Literackiego Henryka Sienkiewicza w Poznaniu, oddziale Biblioteki Raczyńskich. Żona pisarza zajmowała się także realizacją zapomóg, o czym świadczy zachowana w potężnym bloku korespondencji Henryka Opieńskiego karta pocztowa z 3 VII 1916 roku. Skarży się autorka listu, iż nie jest w stanie sprostać ogromowi napływających od licznych rodzin próśb o wsparcie. M. Sienkiewicz, List do H. Opieńskego z 3 VII 1916 r., rkps, Archivum Helveto-Polonicum we Fryburgu, ACR6. Dziękuję Panu Jackowi Sygnarskiemu, twórcy archiwum, za nieocenioną życzliwość w udostępnianiu zbiorów.

15 H. Sienkiewicz, List do I. Chrzanowskiego z 5 X 1915 r., w: tegoż, Listy, t. 1, cz. 1, oprac. M. Bokszczanin, Warszawa 1977, s. 140. Markiem zwykł pisarz nazywać swoją trzecią żonę. Trzy zachowane, zapewne nieodosobnione listy Marii z Babskich, podpisującej się „Henrykowa Sienkiewiczowa”, brzmiały: „Vevey, dn. 22 X 1915 r., Łaskawy Panie, korzystając z cennego pozwolenia załączam list do Warszawy, o który mi tak bardzo chodzi, aby nareszcie doszedł, gdyż pisałam go przed dwoma miesiącami do moich kuzynek bezpośrednio po śmierci ich matki. O ile by po polsku nie można, to niech Łaskawy Pan będzie tak dobry i zwróci. Łączę dla Obojga Łaskawych Państwa wyrazy poważania. Córeczce uprzejmości. CzY I NA HURTOWE PRZESYŁKI W BIURZE LICZYĆ Już MOŻNA?” (wyróżn. - A.A.Ś.); „Vevey, dn. 31 X 1915 r., Łaskawy Panie, Znowuż udaję się z wielką prośbą, aby Łaskawy Pan raczył dopomóc w przesłaniu załączonego listu. Sprawa nie moja, ale tak ważna, iż niemal życie od dojścia tego listu jest zależne osoby nam znajomej. Bardzo, bardzo serdecznie wdzięczna będę Łaskawemu Panu, o ile będzie Pan mógł spełnić ten dobry uczynek, bo o dobrej wierze nie wątpię. Łączę wyrazy poważania, dziękuję i przepraszam”; „Vevey, dn. 20 XII 1915 r., Łaskawy Panie, [...] przesyłam dwa listy do Warszawy z prośbą o łaskawe skierowanie ich gdzie trzeba". List trzeci zawiera również życzenia świąteczne; rkps, Biblioteka Polska Muzeum Narodowego w Rapperswilu, Archiwum Potulickich.

Katalog winiet krakowskich zakładów fotograficznych $w$ zbiorach Muzeum Historii 
Na podstawie zachowanej korespondencji można sądzić o przyjaznych kontaktach i współpracy na polu działań społecznych. Do Karola Potulickiego jako organizatora charytatywnych akcji zwracał się Henryk Sienkiewicz w telegramie, wysłanym 15 grudnia 1915 roku (o godz. 9.15), odebranym w Genewie (o godz. 9.35):

Z powodu choroby, na którą cierpię od dwóch tygodni, nie mogę uczestniczyć w koncercie, z którego dochód jest przeznaczony dla ofiar wojny w Polsce. Niezmiernie żałuję, że nie będę mógł osobiście podziękować artystom i publiczności, która zgromadzi się w tej sali nie tylko w poszukiwaniu wrażeń artystycznych, lecz również po to, aby okazać szlachetne więzi braterstwa między narodami i wesprzeć naród, którego obecne cierpienia można porównać tylko z doświadczeniami jego chwalebnej przeszłości. Chwała tym wszystkim, którzy w epoce nienawiści są dowodem na to, że chrześcijańska miłość i poczucie sprawiedliwości nie umarły. ${ }^{17}$

Prezes Komitetu w poczuciu odpowiedzialności za powodzenie misji filantropijnych wyraził żal, iż jego niedyspozycja fizyczna uniemożliwiała mu osobisty udział w akcji, a zarazem dziękował uczestnikom i organizatorom za hołdowanie wartościom humanitarnym. Pisarz był świadom, że jego obecność jest niezwykle pożądana, oczekiwana, stąd bezpośrednie wyrazy ubolewania. Znać jednak w kurtuazyjnym z pozoru usprawiedliwieniu otuchę, iż w środowisku emigracyjnym - mimo przejawów sporów i walki politycznej - tętni szlachetna działalność.

Wśród znalezionych dokumentów szczególnej wagi nabiera krótki list pisany po polsku przez Sienkiewicza 7 września 1915 roku w Grand Hôtelu:

Szanowny i łaskawy Panie

przepraszam za zwłokę w odpowiedzi, ale wobec stosów listów, które przychodzą każdego tygodnia, nie mogę być pilniejszym. Pański artykuł czytałem i zGADzaM SIĘ Z NIM CA£KowiciE. $Z$ wolna, pod wpływem toczących się wypadków, wszyscy niemal dochodzą do tych samych wniosków - i to dobrze. Równie dobrze jest, że Szanowny Pan zabrał głos w tak poważnym i poczytnym dzienniku, jak „Gazeta Genewska”.

Załączam wyrazy wysokiego poważania Henryk Sienkiewicz. ${ }^{18}$

Fotografi im. Walerego Rzewuskiego w Krakowie, oprac. K. Kudłacz, M. Miskowiec. Zbiory specjalne, Biblioteka Naukowa PAU i PAN w Krakowie, BZS.RKPS.7513.k.22. Utwór w domenie publicznej: http://pauart.pl/app/artwork?id=54a9a413ocf22faa14cbf33d [dostęp 10-09-2016].

17 Telegram nadany w języku francuskim, rkps, Biblioteka Polska Muzeum Narodowego w Rapperswilu, Archiwum Potulickich, przeł. I. Pério.

18 H. Sienkiewicz, List do K. Potulickiego z 7 IX 1915 r., rkps, Biblioteka Polska Muzeum Narodowego w Rapperswilu, Archiwum Potulickich (list drukowany po raz pierwszy); wyróżn. - A.A.S. 
Treść pisma nie wpływa na diametralnie odmienne od dotychczasowych ustaleń określenie orientacji pisarza, jednak pozwala je dopełnić. Potwierdza przy tym poczynione rozpoznania, iż zbliżał się Sienkiewicz do poglądów założonego w lutym 1915 roku przez profesora Jana Kucharzewskiego Stowarzyszenia „La Pologne et la Guerre”, z siedzibą w Lozannie, którego był zresztą honorowym członkiem. Organizacja ta „propagując idee niepodległościowe, zajmowała oficjalnie pozycje neutralne”, a „w rzeczywistości, wrogo nastawione do filorosyjskich koncepcji endeckich”, „sympatyzujących z Legionami" ${ }^{19}$. Zadeklarowana opinia pisarza na temat poglądów członka Stowarzyszenia - Karola Potulickiego wskazuje na poparcie jego racji. Wiadomo, że nie zawsze podzielał sądy ogłaszane przez innych, nawet mu bliskich reprezentantów tej organizacji. Na przykład o broszurze swego syna, Henryka Józefa, na temat odmienności kultury polskiej od rosyjskiej, opublikowanej przez „La Pologne et la Guerre”, napisał w liście z 5 października 1915 roku do Ignacego Chrzanowskiego: „Nie na wszystko się w niej godzę, ale w ogóle rzecz napisana dobrze" ${ }^{20}$.

Cytowany wyżej w całości list umożliwia również - pośrednio za sprawą wypowiedzi publicystycznych adresata listu, Karola Potulickiego - wniknięcie w istotę zapatrywań pisarza, wyrażanych jesienią 1915 roku, po zwrotnym momencie w sprawie polskiej, czyli w okresie po zajęciu Warszawy przez Niemców. To przełomowe zdarzenie wpływało na zmianę poglądów polityków wiążących nadzieje bądź to z obietnicami Rosji, bądź Austro-Węgier.

Wcześniej wyrażane w korespondencji prywatnej stanowisko Sienkiewicza wobec ówczesnych radykalnych poglądów politycznych było - jak wiadomo - krytyczne. Jako prezes Komitetu czuł się zobowiązany do zachowania apolityczności, od której zależało powodzenie akcji ratunkowej poprzez wzbudzenie „sumienia politycznego Europy” "21, jak i skuteczność docierania do wszystkich dzielnic kraju. Niemniej także determinowała tę bezpartyjność niepewność co do rozstrzygnięć konfliktu zbrojnego. Pisarz uważał, iż Polacy powinni przyjąć postawę wyczekującą, po czym dokonać wyboru korzystniejszej oferty rozwiązania polskiej sprawy. Świadczy o tym oburzenie, wynikające $z$ tendencyjnych interpretacji jego poglądów przez reprezentantów różnych opcji:

Czytam ciągle, a przynajmniej od czasu do czasu, w gazetach o rozmaitych moich orientacjach. Czasem się to przykrzy. Wprawdzie i ja często timeo, ale moje stano-

19 W. Śladkowski, dz. cyt., s. 411.

20 H. Sienkiewicz, List do I. Chrzanowskiego $z 5$ X 1915 r., s. 140.

21 H. Sienkiewicz, List II do Stanisława Osady, w: tegoż, Dzieła, pod red. J. Krzyżanowskiego, t. 53, Warszawa 1952, s. 210. 
wisko jest proste. Uczuciowo jest przyjazne dla tych, którzy chcą i mogą zapewnić nam jak najwięcej samodzielności i rozwoju, póki jestem prezesem Komitetu, który musi mieć dostęp do wszystkich dzielnic, jest ściśle neutralne. [...] Najpilniejszą obecnie rzeczą jest ratować zagrożone przez głód i nędzę życie polskie. To ważniejsze od wszelkich „romantyzmów” i realizmów politycznych. ${ }^{22}$

Zawarta w powyższym fragmencie aluzja do cytatu z Eneidy (Timeo Danaos et dona ferentes - „Lękam się Greków, nawet gdy przychodzą z darami”), świadcząca o przyjęciu dystansu wobec płynących od zaborców obietnic, współbrzmi z postawą, jaką przedstawił w swych artykułach Karol Potulicki.

Mimo konsekwencji, z jaką Sienkiewicz utrzymywał Komitet Veveyski na pozycji neutralnej, rozmaici publicyści skłonni byli tendencyjnie odczytywać jego intencje. W taki sposób przedstawiano na przykład sens przedmowy do książki włoskiego pisarza Concetta Pettinata - Sui campi di Polonia (Na polskich rozłogach/polach), wydanej w Mediolanie w 1915 roku. Sienkiewicz w sporządzonym w lutym 1915 roku liście w odpowiedzi na przesłany mu przez włoskiego korespondenta na froncie niemiecko-rosyjskim w Królestwie brulion książeczki otwarcie sformułował swoją diagnozę polityczną. W niej negatywnie scharakteryzował politykę zarówno hakatystycznych Prus, jak i imperialnej Rosji:

Pan umiałeś uwydatnić nasze tragiczne wahania się między nadzieją i zwątpieniem, nasz pęd ku przyszłości zapowiadającej jakoby gruntowną zmianę w życiu Polski, a jednocześnie i zakorzenioną w nas nieufność wobec tej przerażająco ciemnej przyszłości. Znając całowiekową politykę Rosji, zrozumiałeś Pan, że nasze wahania są aż nadto uzasadnione, a na ich zmniejszenie ledwie że wpływają przyrzeczenia gubernatora rosyjskiego oraz głębokie przekonanie, iż zwycięstwo Prusaków równałoby się doszczętnej zagładzie naszego narodu. ${ }^{23}$

W liście Sienkiewicz odwoływał się do przeświadczenia o ścisłym związku Polski z cywilizacją zachodnią i do narodowej mitologii, jaka upamiętniła ofiary walki o wolność. Jako rzecznik postulatu zadośćuczynienia swej ojczyźnie za męczeństwo, zdeprawowanie i heroizm zachowywał jednak trzeźwą świadomość i dystans wobec politycznych gestów zaborców:

Ze strony Rosji, zawsze wrogiej duchowi Zachodu, przyszło jej wycierpieć tak wiele,

22 H. Sienkiewicz, List do I. Chrzanowskiego z 24 XI 1915 r., w: tegoż, Listy, t. 1, cz. 1, S. $142-143$.

23 Cyt. za: J. Birkenmajer, Z pamiątek po Sienkiewiczu, „Myśl Narodowa” 1930, nr 3, s. 37-38. Przedruk przedmowy w przekładzie J. Birkenmajera, w: H. Sienkiewicz, Dzieła, t. 54, Warszawa 1952, s. 143-144. Fragmenty przedmowy podała w kwietniu 1915 roku prasa polska (np. „Kurier Poranny” 23 IV, nr 112), całość ukazywała się w kolejnych wydaniach książki włoskiego pisarza, począwszy od 1915 roku. 
że nieoczekiwana zmiana w postępowaniu ciemiężyciela wywołuje w niej zdumienie, niepozbawione i niepokoju. Czułaby się szczęśliwą, gdyby istotnie raz na zawsze zamknął się dla niej okres męczeństwa... niestety, zbyt trudną dla niej rzeczą byłoby zapomnieć o cierpieniach tak jeszcze niedawnych. Cały kraj pamięta, że polityka rosyjska w stosunku do niego zawsze ściśle i niewolniczo ulegała podszeptom Berlina, niepodobna też przeoczyć, że pomimo przepaści, jaka dziś dzieli oba mocarstwa, wspomniana polityka wciąż jeszcze postępuje dawnym torem. ${ }^{24}$

Poglądy pisarza, ujawniające rezerwę, były jednak przedmiotem złośliwych insynuacji. Na łamach dedykowanych Legionom „Listów ulotnych” były przedstawiane jako przejaw potępianego rusofilstwa. Zdaniem autora jednej z odezw potępiającej rzekomą bezpartyjność Komitetu Veveyskiego, argumentem potwierdzającym orientację „rosyjską” autora Potopu jest jego stwierdzenie z przedmowy do książki Pettinata, że zwycięstwo niemieckie oznacza „zagładę polskości” ${ }^{25}$. Charakter rusofilski jego postawy, udowadnianej także w oparciu o inne opinie, między innymi agentów rosyjskich ${ }^{26}$, każe działaczowi zdać się na przyszły osąd historii i odrzucenie wielkiej roli pisarza: „[...] nie chcemy w nim żadną miarą widzieć reprezentanta politycznych myśli i uczuć narodu polskiego" ${ }^{27}$. Podzielający przedstawione przekonania Władysław Studnicki apelował w liście otwartym do Henryka Sienkiewicza o patronowanie obozowi Legionów Piłsudskiego:

Ludzie pokolenia Pana, pokolenia upodlonego niewolą, strachem, jaki panował w narodzie w epoce represalii popowstaniowych, oraz karierowicze starają się Szanownego Pana wciągnąć do kontrakcji, do akcji na korzyść Rosji. Ale autor Potopu instynktownie od akcji moskalofilskiej się odwraca. Ponieważ jednak wielki artysta nie posiada wielkiego usposobienia politycznego, stąd pociągnięto go do koncepcji neutralności. [...] Przedstawiciele jej mniemają, iż nie ponoszą odpowiedzialności za wypadki dziejowe, przed nimi się rozgrywające, gdy propagują bierność, nie pomnąc na to, iż tym siłę już wszczętej akcji osłabiają. [...] Dzieło Legionów jest jednym z czynników akcji antyrosyjskiej. ${ }^{28}$

\section{Tamże.}

W.B., Polityka czy filantropia?, s. 34.

Przykładem dla publicysty jest opinia posła do Dumy, przytaczana w książce La Russie et la guerre, wręcz określająca Sienkiewicza mianem rusofila (tamże, s. 33).

Tamże, s. 34. Osąd historyka współczesnego okazuje się potwierdzać słuszność drogi, jaka doprowadziła do niepodległości. Por. H. Florkowska-Frančić, Od akcji propagandowej do dyplomatycznej. Zabiegi o uznanie przez Szwajcarię państwa polskiego w latach 1918-1919, w: Polska i Polacy w XIX i XX wieku. Studia ofiarowane Profesorowi Mariuszowi Kulczyckiemu w 7o. rocznicę Jego urodzin, pod red. K. Ślusarka, Kraków 2002, s. 193-209.

Do Henryka Sienkiewicza. Z listu otwartego Władysława Studnickiego, „Listy Ulotne do Emigracji Polskiej w 1915 r." (Lozanna), t. 1 (sierpień), s. 20. 
W perswazyjnym wywodzie sięgnął autor po dość zuchwałą formę imputowania pisarzowi jego zapatrywań, opierając się na schematycznym odbiorze Trylogii jako dzieła tyrtejskiego. Zarzucając Komitetowi Veveyskiemu, iż za maską neutralności kryje on swą wysługującą się Rosji politykę, Studnicki przestrzegał pisarza przed poniesieniem odpowiedzialności moralnej ${ }^{29}$.

Gorączkowość w odbiorze sprzecznych poglądów prowadziła zatem do rozmaitych nieporozumień i napastliwych złośliwości. Tymczasem, jak trafnie stwierdził Józef Birkenmajer, stanowisko pisarza odzwierciedlało całą linię ideową jego twórczości. Jego wypowiedź była świadectwem tego, że:

Autor Krzyżaków i Bartka Zwycięzcy jeszcze na schyłku swego żywota widzi w Niemcach najgroźniejszych i najzawziętszych wrogów narodu polskiego, jednocześnie nie dowierza i Rosji, znając jej obłudę i niższość kulturalną; wspomina ukaz tolerancyjny, w którego sprawie w swoim czasie głos zabierał. Konsekwentność myśli widzimy i w tej niezłomnej wierze, że pomimo wszelkich „opresyj” Polska przetrwa i zwycięży, nie ulegnie rozbiciu i zagładzie. To było przecie kiedyś myślą przewodnią Trylogii i to samo tętniło i w powieści podjętej w zaraniu wojny i niedokończonej - w Legionach. ${ }^{30}$

Sienkiewicz, w związku z szerzącymi się oskarżeniami o szkodliwą politykę oraz dążeniami ze strony różnych orientacji do wykorzystania go dla ich partykularnych celów, ogłosił na łamach „Głosu Narodu” odezwę W sprawie Komitetu Generalnego w Vevey, by zapobiec jątrzeniu środowisk emigracyjnych. Pisarz w swym objaśnieniu narosłych pretensji usiłował łagodzić spory:

Komitet dzieli całym sercem uczucia i nadzieje narodu: każdy z nas pojedynczo zastrzega sobie prawo głosu w drogiej nam wszystkim sprawie, ale Komitet, jako instytucja, dopóki się nie rozwiąże i dopóki ja należę do prezydium, będzie szedł zawsze dotychczasową drogą i będzie miał przed oczyma jeden wyłączny cel: ratunek dla starych gniazd ojczystych i dla żyjącego w nich ludu. ${ }^{31}$

Swoje stanowisko zasadniczo motywował prostą zależnością, iż najpierw należy ratować byt, by następnie na tym gruncie organizować państwo, wznosić „gmach przyszłości”: „inaczej nie będzie z czego budować” ${ }^{32}$. Dla tego celu potrzebne jest też opanowanie i zdroworozsądkowa ocena sytuacji politycznej. Postawę taką znalazł w członku „La Pologne et la Guerre”, co ujawnił w liście z wyznaniem, iż „zgadza się z nim całkowicie”.

29 Tamże.

30 J. Birkenmajer, dz. cyt., s. 38.

31 H. Sienkiewicz, W sprawie Komitetu Generalnego w Vevey, „Głos Narodu” 1916, nr 83, w: tegoż, Pisma zapomniane i niewydane, oprac. I. Chrzanowski, Lwów 1922, s. 572.

32 Tamże, s. 570. 
Słowa uznania ze strony Sienkiewicza odnosiły się do poglądów przedstawionych przez Karola Potulickiego w artykule Le problème polonais na łamach „Journal de Genève” w numerze z 2 września 1915 roku. Tekst ten pojawił się w gąszczu wielu głosów polskich, prezentowanych w prasie francusko-szwajcarskiej, obok wypowiedzi innych narodowości poruszających kwestie: armeńską, żydowską, czeską, łotewską, litewską, rusińską, serbską, belgijską. Jednak publikacja $\mathrm{w}$ jednym $\mathrm{z}$ największych i wpływowych dzienników Szwajcarii romańskiej umożliwiała jej znaczącą pozycję.

„Journal de Genève” był organem konserwatywnych liberałów, przewyższając drugi opiniotwórczy, pokrewny politycznie organ „Gazette de Lausanne" szybszym obiegiem informacji, prężnie wydawanym pod kierownictwem Georges’a Wagnière’a. Jak stwierdziła Halina Florkowska-Frančić, artykuły na łamach „Journal de Genève” „szerzej i bardziej obiektywnie traktowały sprawę polską" niż wypowiedzi publikowane w "Gazette de Lausanne”, pozostającej pod wpływem Agencji lozańskiej ${ }^{33}$. Z odpowiedzialnością - jak referował Baranowski - na łamach genewskich przedstawiał problem polski znany dziennikarz Albin Bonnard, przyznając prawo do niezależności:

Artykuły jego o Polsce pisane są zawsze w duchu antyniemieckim, konstatuje w nich jednak antyrosyjski front Polaków, nie narzuca im bezwzględnie orientacji „ententowej” [reprezentowanej przez „Journal de Genève”, jak i Szwajcarów - przyp. A.A.S.] i - acz z pewną cierpkością - konstatuje zmiany na lepsze w Polsce okupowanej. $^{34}$

Wypowiedź na łamach ważnego genewskiego organu cieszyła zatem Sienkiewicza z uzasadnionych względów. Konsekwencją oddziaływania mądrze przedstawionego stanowiska była zarówno materialna pomoc Polsce dewastowanej przez niszczycielskie armie, jak i sympatia dla jej dążeń niepodległościowych uniezależnionych od Rosji.

Artykuł Potulickiego zasługiwał zdaniem współczesnych na wyróżnienie z uwagi na wytworność i obiektywizm. Po odniesieniu do ostatnich wydarzeń z pola wojny (odebranie Lwowa, zajęcie Warszawy) autor stwierdzał niezaprzeczalne fakty, że - jak streszcza jego wywód Władysław Baranowski - „los Polski rozgrywa się obecnie na polach bitwy, ona sama zaś służy raz za stawkę, to znów za zakładnika i będzie jeszcze przedmiotem licznych a olbrzymich targów na polu dyplomacji, wobec czego wskazanym jest zdać

W. Baranowski, Sprawa polska w prasie francusko-szwajcarskiej, s. 8. 
sobie sprawę z różnych możliwości, jakie mogą z konfliktu tego dla Polski wyniknąć" 35 .

Wypowiedź Potulickiego zaznajamiała z sytuacją Polski poprzez zarys stosunków polsko-niemieckich, polsko-austriackich i polsko-rosyjskich w trzech zaborach, przekonując, iż najlepsze warunki otrzymała dzielnica austriacka: możliwość rozwoju intelektualnego i ekonomicznego, podczas gdy „hakatyzm i pangermanizm niemiecki, brutalny pruski Kulturkampf, wywłaszczenia, tak samo jak i system represyjny i prześladowczy rządu rosyjskiego wywołały w obu zaborach skrytą, lecz silną walkę o byt narodowy" ${ }^{36}$. Działacz charakteryzował również zróżnicowaną postawę ciemięzców wobec polskich aspiracji niepodległościowych, we wszystkich przypadkach wkalkulowanych w ich interes wojenny. Podkreślał, że Polacy wbrew manipulacjom nie zeszli z drogi honoru: „[...] wobec straszliwej rzeczywistości, która zmuszała ich do walki bratobójczej, pozostali wierni etycznym tradycjom swej historii, wolnej od skrytobójstwa i podłych zdrad i spełnili w armiach obcych swój obowiązek, padając na polach bitew" ${ }^{37}$.

W odniesieniu do sprzeczności występujących w polskich stanowiskach politycznych Potulicki objaśnił, iż zachodzą między nimi pozorne przeciwieństwa, wynikające z tendencyjnego wykorzystania polskiej dzielności przez wrogów. Szlachetny polski zryw legionowy, podyktowany lojalnością i zaufaniem wobec rządu Austrii, ponoszący ofiarę z życia, stał się przyczyną rozłamu wśród jednolitych aspiracji narodowych. Przyczyniła się do tego akcja prasy pangermańskiej, która w zestawieniu z milczeniem sfer w Berlinie i mglistością obietnic Wiednia, pod wpływem obietnic wielkiego księcia Nikołaja Nikołajewicza w Królestwie, niepotwierdzonych wszakże w praktyce, wytworzyła przekonanie, że galicyjski czyn przysługiwał się hakatystom. Późniejsze szykany, represje ze strony rządu rosyjskiego otrzeźwiły koła rusofilskie. Dlatego działacz przewidywał, że w decydującym momencie Polacy staną zjednoczeni i pojednani. W nadziei na powstanie niezależnego państwa polskiego, będącego gwarancją pokoju w Europie, autor przedstawił szereg kandydatów do tronu spośród książąt niemieckich: jednego z synów Wilhelma, Koburga, Karola Stefana (takiej szansy nie dawała deklaracja rosyjska). Zakończył omówienie etyczną przestrogą przed powtórzeniem zbrodni z roku 1795.

Zawartość myślowa artykułu Potulickiego nie mogła budzić zastrzeżeń

36 Tamże.

37 Tamże, s. 15. 
Sienkiewicza. Prawnik ujmował problem obiektywnie, bez tendencyjnych wyjaskrawień, formułując spostrzeżenia i postulaty, jakie dyktował nade wszystko interes sprawy polskiej. Stanowisko dyplomaty wypływało z założeń, które były bliskie autorowi Quo vadis?.

Szerzej omówił Potulicki swoje stanowisko w głośnym artykule La Pologne d'hier et de demain (Polska wczoraj i jutro). Głównym zadaniem broszury było przedstawienie argumentacji za przywróceniem niepodległości Polski, zatem przekonanie do kasacji rozbiorów. Postawił w tej francuskojęzycznej rozprawce następującą tezę:

Polska jest filarem Europy... Jest wyspą Świętej Heleny, gdzie pozbawiona iluzji przenikliwość wielkiego człowieka, Napoleona I, który podsumował swoje dzieło i nie oczekuje już niczego od życia, formułuje tę prawdę, żałując być może, że nie zauważył jej wcześniej; to piedestał interesów Europy, na którym politycy mianowani do stworzenia podstaw trwałego pokoju będą musieli powołać tę prawdę do życia. Grzęzawisko polityki opartej na uprzedzeniach, konszachtach, żalach i pułapkach nie pozwoliłoby im ogarnąć wzrokiem całego ogromnego budynku aere perennius, który należy zbudować, tej świątyni pokoju, której strażnikiem byłaby niezależna Polska. ${ }^{8}$

Przekonując opinię europejską do zmiany stanowiska w sprawie niezależnej Polski, wysuwał racje oparte na przekonaniu o jej moralnych predyspozycjach do roli, jaką wyznaczał w przyszłym układzie sił politycznych. Było to zadanie szczytne: polegałoby na konsolidowaniu przyszłego pokoju między panslawizmem a pangermanizmem. Ponadto stworzenie państwa zapobiegłoby nieustannym przejawom wrogości narastającej wśród Polaków wobec narzucanej przymusem obcej kultury. Umożliwiłoby również stworzenie równowagi w stanie posiadania walczących ze sobą państw zaborczych.

Nie ma osobnego świadectwa listowego poparcia Sienkiewicza dla poszerzonego oglądu kwestii polskiej, przeprowadzonego na łamach „Przeglądu Polityki Międzynarodowej”, można jednak sądzić, że przyjął go pisarz z uznaniem. Pośrednim wskazaniem przychylności jest cytowany już telegram (15 grudnia 1915 roku) z okresu publikacji tej broszury. Działania Potulickiego były dyktowane, jak się w nim wyraził Sienkiewicz, przez „chrześcijańską miłość i poczucie sprawiedliwości”. Określił tak istotny punkt zbieżny wystąpień własnych oraz energicznego dyplomaty. Myśl ta wyrasta - analogicznie do stanowiska Sienkiewicza - z pragnienia wprowadzenia więzi opartych na miłości bliźniego w miejsce podyktowanych egoizmem relacji. Podobnie jak on jako autor Listu otwartego do Wilhelma II króla pruskiego (1906)

38 K. Potulicki, La Pologne d'hier et de demain, „Revue Politique Internationale” 1915 (listopad-grudzień), odb. Lausanne 1915, s. 5. Ten i inne cytaty z tego opracowania - przeł. I. Pério. 
czy Listu otwartego do ministra rosyjskiego (1904), występował niejednokrotnie, powołując się na uszanowanie cywilizacyjnych wartości w imię sprawiedliwości dziejowej. Karol Potulicki domagał się zaś jej równie dobitnie, przekonując państwa europejskie do korzyści, jakie odniosą dzięki przywróceniu państwowości polskiej. Konieczność naprawienia ponadstuletniego błędu upoważniała go do stwierdzenia, iż wojna światowa zostanie w przyszłości nazwana „wojną Polski za Polskę” ${ }^{39}$.

W rozprawie La Pologne d'hier et de demain pojawił się tożsamy z przekonaniem Sienkiewicza sąd wyrażony przezeń choćby w Odpowiedzi na list otwarty Chéradame’a (1910), iż „ucisk i prześladowanie nie leżą w polskim charakterze" ${ }^{40}$. Posłużył on jako argument, iż to uwarunkowanie pozwoli stworzyć cywilizacyjne ramy współpracy międzynarodowej. Pisał Potulicki o Polsce:

[...] taki kraj znajdujący się w centrum Europy przedstawia punkt oparcia dla równowagi wielkich środkowych mocarstw i gwarancję pokoju dla innych. Jest nią tym bardziej, iż duch podboju i drapieżne ambicje od zawsze były obce niezwykle tolerancyjnemu polskiemu charakterowi, „który zawdzięcza wyłącznie tej tolerancji jak potwierdza Rulhière - poszerzenie swoich granic i przyłączenie wszystkich sąsiednich krajów". Ów brak bojowniczego i spekulanckiego temperamentu od zarania przygotowywał Polskę, jak mało który kraj, do roli kraju buforowego, stosując równie jasne, co mało eleganckie wyrażenie, a przede wszystkim do roli strażnika pokoju i teraz powinniśmy powitać jej opatrznościowy powrót do wolnych narodów Europy. ${ }^{41}$

W tym duchu pisał również autor Wirów w przedmowie do książki Concetta Pettinata, iż „Polska jest pośród wszystkich krajów zamieszkiwanych przez szczep słowiański jedyną wielką przedstawicielką cywilizacji zachodniej”, co narażało ją stale na prześladowania ze strony Rosji, „zawsze wrogiej duchowi Zachodu" ${ }^{42}$. Koncepcja ta pozwala zdaniem autora wyznaczać Polsce centralne miejsce w Słowiańszczyźnie jako ostoi kultury chrześcijańskiej. Uznawał, iż urzeczywistnienie jej bytu państwowego pozostawało zatem w interesie krajów europejskich.

Potulicki podzielał również zapatrywania Sienkiewicza na temat skutków imperializmu carskiego. Jednoznacznie obalał złudę rzekomych gestów wspaniałomyślności:

Tamże, s. 12.

H. Sienkiewicz, Odpowiedź na list otwarty Chéradame’a, w: tegoż, Pisma zapomniane i niewydane, s. 523.

41 K. Potulicki, La Pologne d'hier et de demain, s. 5-6.

42 H. Sienkiewicz, Dzieła, t. 54, s. 144. 
Ta rządowa koncepcja panslawizmu, narzucona Europie przez Piotra Wielkiego i wpajana Rosji przez jego następców, od zawsze była odpychająca i antypatyczna dla Polaków pozostawionych na pastwę hordy dużych i małych urzędników pracujących w imię tego właśnie rosyjskiego panslawizmu. Hybryda powstała wskutek słowiańskiej opieszałości i krzyżackiej brutalności, orientalnej dwulicowości i mongolskiej naiwności, bezlitosnego prozelityzmu i ironicznego sceptycyzmu — rosyjski panslawizm spowodował głębokie pęknięcie między Polską a Rosją. Aby wypełnić tę głębię, należałoby wrzucić do niej całe rusztowanie kulawego systemu; do zrealizowania tej trudnej, a zarazem pięknej misji, nie wystarczy więc manifest - kawałek papieru, jeden $\mathrm{z}$ wielu! ${ }^{43}$

Przywołana ocena Rosji, zaprzeczająca wizji rusofilskiej, wyklucza przypisywane Potulickiemu przez autorkę biogramu w Polskim słowniku biograficznym, Alinę Szklarską-Lohmannową autorstwo anonimowej broszury prorosyjskiej La Question Polonaise par un Polonais de Posnanie, napisanej jesienią 1915 roku w reakcji na zajęcie Warszawy przez Niemców ${ }^{44}$. Tożsamy obraz wschodniego zaborcy-ciemiężyciela wyłaniał się z politycznych artykułów Sienkiewicza: anonimowego zarysu ogłoszonego w amerykańskim piśmie „Daily Evening Post” z 8 września 1877 roku: Poland and Russia. The czar's Government in Poland and on the Danube (Polska i Rosja. Rzad carski $w$ Polsce i nad Dunajem) ${ }^{45}$, jak i później w broszurze List otwarty Polaka do ministra rosyjskiego (1904). Nie traciły aktualności poczynione już w 1877 roku Sienkiewiczowskie rozpoznania hipokryzji Rosji, która w masce „protektorki Słowiańszczyzny” dokonywała „rozbioru najsławniejszego i najbardziej oświeconego państwa słowiańskiego”, „podzieliła żywy kraj, słowiański z krwi i kości, i zrobiła to do spółki z Niemcami, odwiecznym wrogiem Słowiańszczyzny”, a jej rządy „zabiły naród, okradły go z istnienia politycznego, odbierając mu prawa do samostanowienia i samorządu, i wszystkiego innego" ${ }^{46}$. Mimo upływu wielu dekad dyrektywy autokratyzmu pozostały nie-

43 K. Potulicki, La Pologne d'hier et de demain, s. 6-7.

44 Por. Polski słownik biograficzny, t. 28, Wrocław 1985, s. 249. Temu rozpoznaniu zdaje się też przeczyć Halina Florkowska-Frančić, wskazując na Erazma Piltza - por. H. Florkowska-Frančić, Między Lozanną, Fryburgiem i Vevey, s. 254.

Zob. J. Bukowiecki, Pierwszy artykuł polityczny Henryka Sienkiewicza, „Wiadomości” (Londyn) 1965, nr 4, s. 1-2. Szerzej zagadnienie poglądów Sienkiewicza na temat wschodniego mocarstwa omawiam w artykule Henryk Sienkiewicz wobec Rosji, w: Między rusofobią a rusofilia. Poglady, postawy i realizacje w literaturze polskiej od XIX do XXI wieku, pod red. S. Karpowicz-Słowikowskiej, E. Mikiciuk, T. Sucharskiego, Gdańsk 2016, s. 71-93.

46 [H. Sienkiewicz], Poland and Russia. The czar's Government in Poland and on the Danube, „Daily Evening Post” (San Francisco), 8 IX 1877. Cyt. za: J. Bukowiecki, dz. cyt., s. 1. 
zmienne, a zatem postanowieniami rządziła obłuda i przewrotność. Potulicki stwierdzał, że rosyjskie podejście do sprawy polskiej dowodzi tego, że wpływowe sfery rządzące niczego się nie nauczyły. Tym samym jego wątpliwości budził sojusz Rosji z Francją:

Ubolewamy nad mezaliansem z Francją „republikańską i ateistyczną”, zgodnie z przyjętym stereotypem, lecz mimo wszystko mamy nadzieję, że ta małżeńska eskapada zakończy się prawomocnym rozwodem, którego koszty — po raz który? — pokryć będzie musiała Polska. ${ }^{47}$

Obawy dotyczące pozycji Francji wyrażał także Sienkiewicz, który przewidywał, jak wspominał Wincenty Witos, że „nie będzie [ona] zdolna sama unieść ciężaru wojny do końca, jak również zdobyć głosu decydującego przy układach pokojowych" ${ }^{48}$.

Ostrożność nakazywała również osławiona polityka w pruskim zaborze: działalność wykupywania ziemi, należącej do Polaków, by osadzać na niej Niemców, jak też przymusowego wywłaszczania Polaków podległych rządowi pruskiemu. Był ofiarą tej polityki Karol Potulicki, kiedy na początku 1909 roku z zamiarem przeniesienia się do Francji sprzedał swe majątki Stefanowi Götzendorf Grabowskiemu, podstawionemu przez Niemców agentowi, który niebawem odstąpił je pruskiej Komisji Kolonizacyjnej. Dezydery Chłapowski sprzedaż tę określił mianem lekkomyślności ${ }^{49}$, lecz ta subtelna ocena była odosobniona. Incydent ten stał się podstawą do wysunięcia bezwzględnych zarzutów, mocno wzburzył opinię publiczną w Wielkopolsce. Ostrą kampanię prasową przeprowadził redaktor „Kuriera Poznańskiego”, organu Narodowej Demokracji, Marian Seyda, oskarżając Potulickiego o świadomą zdradę narodową. Sprawę rozstrzygnął obywatelski sąd honorowy werdyktem uniewinniającym (1o lipca 1909 roku) ${ }^{50}$, można jednak sądzić, iż to doświadczenie wycisnęło piętno na postawie działacza niepodległościowego, nauczyło rozwagi i przezorności względem podstępnej polityki zaborców. Na podstawie własnych doświadczeń Potulicki piętnował metodyczną germanizację:

Całkowity zakaz używania języka polskiego w szkołach, sądach, na zebraniach publicznych i we wszystkich instytucjach państwowych, zakaz sprzedaży ziemi przez

47 K. Potulicki, La Pologne d'hier et de demain, s. 10.

48 W. Witos, Moje wspomnienia. Dzieła wybrane, t. 1, oprac. W. Karczewski, J.R. Szaflik, Warszawa 1988, s. 339.

49 D. Chłapowski, Chłapowscy: kronika rodzinna, Warszawa 1998, s. 141.

50 K. Potulicki, [Akta sprawy przeciw Karolowi Potulickiemu o sprzedaż majątku Kruszewo], Kościan 1909. 
polskich właścicieli bez zgody władz dysponujących prawem pierwokupu, „legalne” wywłaszczanie polskich właścicieli na rzecz przybyłych z Niemiec kolonizatorów, odsunięcie od wszelkich stanowisk państwowych - to zaledwie kilka przykładów z całej serii despotycznych działań wymierzonych przeciwko Polakom w Poznańskiem - regionie będącym kolebką ich ojczyzny. ${ }^{51}$

Pamięć o polityce eksterminacyjnej Niemiec, prowadzonej wspólnie z Rosją, była też przyczyną zachowania przez Sienkiewicza dystansu wobec nacisków admiratorów obietnic z germanofilskiej opcji politycznej. Zjawiska, „urągające cywilizacji, prawu, sprawiedliwości i tym wszystkim pojęciom humanitarnym, które są podstawą życia i kultury nowożytnych społeczeństw" ${ }^{52}$, nakazywały wspartą na historycznym doświadczeniu przezorność.

Wiele wnikliwych i obiektywnych artykułów Karola Potulickiego ukazujących w prasie szwajcarskiej polskie zapatrywania miało znaczący wpływ na przebieg dyskusji prowadzonych w kręgach emigracji szwajcarskiej. Debaty programowe znalazły w nim wybitnego przedstawiciela, co zostało potwierdzone powierzeniem mu sekcji informacyjnej organizacji „La Pologne et la Guerre”. Jak zaznaczył Leszek Gawor, odnosząc się do trafności dokonanych przez Potulickiego spostrzeżeń, cechowała je rzadka wnikliwość. Pozwoliła mu ona zdiagnozować późniejsze „przesunięcie punktu ciężkości świata z Europy (zawłaszczanej w sytuacji jej upadku) na rzecz albo panislamizmu albo panamerykanizmu, jednocześnie zaznaczając, że ten wymiar zagrożenia nie jest powszechnie dostrzegany" ${ }^{53}$.

Aprobata Sienkiewicza dla tez ogłoszonych przez Potulickiego w zwrotnym momencie dziejowym jesienią 1915 roku stanowi nie tylko przejaw zachodzącej ewolucji orientacji politycznych pisarza pod wpływem biegu wydarzeń, co uzasadnia jego późniejszy pozytywny stosunek do ogłoszenia aktu 5 listopada 1916 roku. Wgląd w obiektywny opis sytuacji politycznej determinującej działania Sienkiewicza jako prezesa Komitetu Veveyskiego rekonstruuje skomplikowane uwarunkowania jego pozycji.

Rozeznanie okoliczności związanych z powstaniem listu wyrażającego

51 K. Potulicki, La Pologne d'hier et de demain, s. 7.

52 H. Sienkiewicz, Ankieta o wywłaszczeniu, w: tegoż, Dwie łąki, s. 193. W prasie krajowej artykuł ten ukazał się dopiero w wolnej Polsce na łamach „Tygodnika Ilustrowanego" ze słowem wstępnym wiedeńskiego dziennikarza Bernarda Scharlitta Prusy i Europa. W sprawie wywłaszczenia Polaków. B. Scharlitt, Henryk Sienkiewicz. Prusy a Europa. Nieznana dotąd w Polsce praca autora „Trylogii” w sprawie wywłaszczenia Polaków, „Tygodnik Ilustrowany” 1924, nr 43, s. 701-703. W kwestii tej pisarz zabierał głos niejednokrotnie.

53 L. Gawor, Katastrofizm w polskiej myśli społecznej i filozofii: 1918-1939, Lublin 1999, S. 141. 
poparcie Sienkiewicza dla poglądów Karola Potulickiego odsłoniło jedną z kart kroniki działalności emigracji szwajcarskiej. Ukazało bliżej nieznane uwikłanie prezesa Komitetu Veveyskiego w struktury środowisk rzeczników sprawy polskiej, którym stawiał wysokie wymagania. W świetle relacji pisarza z Potulickim wysnuć można wniosek, że jego oczekiwania nie były złudne, mógł liczyć na wsparcie szlachetnych współpracowników.

Analiza zapatrywań na przełomową chwilę dziejową w czasie „wielkiej wojny” pozwala także zrozumieć motywy, jakimi kierował się autor Quo vadis?, oraz poznać trudności, z jakimi się zmagał. Ujawnienie tych zależności utrudniających zachowanie apolityczności wskazuje na zasadnicze rysy politycznego oblicza pisarza uwikłanego w ciągłą walkę i narażonego na nieustanną krytykę zwalczających się kręgów społecznych. Obrazuje zarazem jego refleksje o polskiej przeszłości i politycznej teraźniejszości, co skłania do wysnuwania nauk politycznych z myślą o postulowanym idealistycznie solidarnym funkcjonowaniu narodów.

Z rozważań tych wyłania się w naturalny sposób portret pisarza. Jednym z jego rysów jest dbałość o godność narodową, wypływającą ze świadomości praw każdego narodu do swobodnego rozwoju i wyrastającą ze wzniosłych przejawów tradycji, jaką może się szczycić. Równie istotna była troska o kondycję moralną społeczności jako gwarancji wszczęcia mądrej polityki odrodzonej państwowości. Fundamentem, na jakim miałaby się wspierać, był powszechnie głoszony w wielu odezwach, ale niewprowadzony w życie postulat jedności. Najistotniejszym zatem przekonaniem wybrzmiewającym z oglądu zbieżności poglądowych z działaczami politycznymi jest ponadczasowa i w gruncie rzeczy apolityczna prawda, wypowiedziana przez Sienkiewicza dobitnie jeszcze w odezwie Zjednoczenie narodowe:

Stronnictwa, bez względu na dzielące je różnice i barwy, mogą w pewnych doniosłych chwilach działać w sposób zgodny i jednolity ale wspólnie zorganizowany, a powinny działać tak zawsze w czasach wielkich, grożących narodowi niebezpieczeństw i wobec olbrzymich zadań, które z natury rzeczy wymagają solidarności. ${ }^{54}$

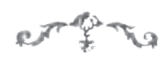

A B S T R A C T

Henryk Sienkiewicz in Relation to the Political Views of the Polish Emigration in Switzerland

The author presents the political opinions of Henryk Sienkiewicz, which he displayed during the final two years of his life, when he was 
the chairman of the Vevey-based General Committee of Aid for the War Victims in Poland. The article particularly focuses on the analysis of his political views at the end of 1915, in the light of his previously unknown correspondence written to Count Karol Potulicki. During the First World War, Count Potulicki was strongly campaigned for the freedom of Poland in Swiss press. He was an activist of La Pologne et la Guerre association, founded by Jan Kucharzewski. Sienkiewicz was an honorary member of this organisation. The writer was neutral and apolitical, but in unofficial statements he did not try to hide his political views or beliefs. The analysis of the agreement between the writer and the journalist shows their unanimous perception of the general situation and as to what was required to aid the cause of Poland regaining independence.

\section{KE Y W O R S}

First World War, Henryk Sienkiewicz, Karol Potulicki, Swiss press 